\title{
Laparoscopic gastrectomy with lymph node dissection for gastric cancer
}

\author{
Norio Shiraishi, Kazuhiro Yasuda, and Seigo Kitano \\ Department of Surgery I, Oita University Faculty of Medicine, 1-1 Idaigaoka, Hasama-machi, Oita 879-5593, Japan
}

\begin{abstract}
Since 1991, laparoscopic surgery has been adopted for the treatment of gastric cancer, and it has been performed worldwide, especially in Japan and Korea. We reviewed the English-language literature to clarify the current status of and problems associated with laparoscopic gastrectomy with lymph node dissection as treatment for gastric cancer. In Japan, early-stage gastric cancer (T1/T2, N0) is considered the only indication for laparoscopic gastrectomy. As yet, there is little high-level evidence based on long-term outcome supporting laparoscopic gastrectomy for cancer, but reports have provided level 3 evidence that the procedure is technically safe, and that it yields better short-term outcomes than open surgery; that is, recovery is faster, hospital stay is shorter, there is less pain, and cosmesis is better. However, investigation into the oncological outcome of laparoscopic gastrectomy as treatment for cancer is lacking. To establish laparoscopic surgery as a standard treatment for gastric cancer, multicenter randomized controlled trials to compare the short- and longterm outcomes of laparoscopic surgery versus open surgery are necessary.
\end{abstract}

Key words Stomach - Cancer - Laparoscopic gastrectomy · Lymph node dissection

\section{Introduction}

Since laparoscopic cholecystectomy was first performed in 1990 in Japan, about 30000 patients with gastrointestinal disease have undergone laparoscopic surgery [1]. Laparoscopic surgery with a small laparotomy reportedly has several advantages over conventional open

Offprint requests to: N. Shiraishi

Received: January 19, 2006 / Accepted: April 19, 2006 surgery, including less invasiveness, less pain, earlier recovery, and better cosmesis [2]. Kitano et al. [3] first applied and described laparoscopy-assisted distal gastrectomy (LADG) as treatment for early gastric cancer (EGC) in 1994.

With the development of various diagnostic modalities and the spread of mass screening, EGC now accounts for more than $50 \%$ of the total incidence of gastric cancer in Japan. The low frequency of lymph node metastasis in patients with EGC is well known; it reportedly occurs in $2 \%-5 \%$ of those with mucosal cancer and $11 \%-20 \%$ of those with submucosal cancer [4]. To allow for the treatment of EGC in patients without a risk of lymph node metastasis, laparoscopic wedge resection (LWR) with a lesion-lifting method was developed by Ohgami et al. [5] in 1992, and intragastric mucosal resection (IGMR) was developed by Ohashi [6] in the early 1990s. With the recent development of endoscopic mucosal resection (EMR) and endoscopic submucosal dissection (ESD) [7], the use of LWR and IGMR seems to be decreasing, whereas the use of LADG with lymph node dissection has increased in patients with EGC with a risk of lymph node metastasis.

The past 15 years have seen remarkable advances in laparoscopic surgical techniques and instruments, such as laparoscopic coagulating shears [8]. Extended lymph node dissection (D2) and total gastrectomy can now be performed laparoscopically $[9,10]$. However, LADG remains controversial as a standard surgery for gastric cancer because there are few studies evaluating the technical difficulty, advantages, and oncological feasibility of LADG.

Here, we review reports, in the English-language literature, of LADG with lymph node dissection as treatment for cancer, to clarify the current status of this technique and related problems. 


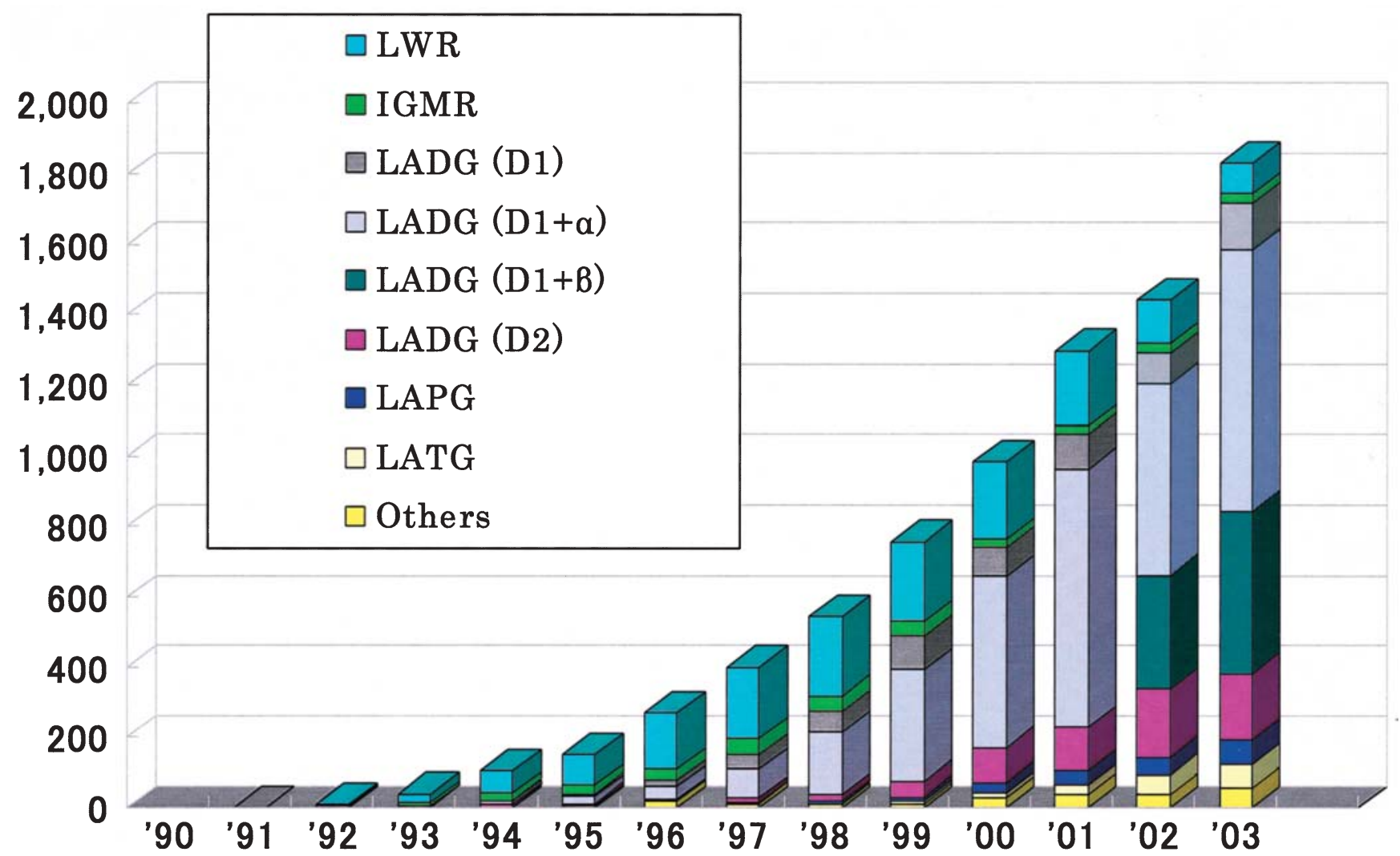

Fig. 1. Laparoscopic surgery for gastric cancer. $L W R$, Laparoscopic wedge resection; $I G M R$, intragastric mucosal resection; $L A D G$, laparoscopy-assisted distal gastrectomy; $L A P G$, laparoscopy-assisted proximal gastrectomy; $L A T G$, laparoscopyassisted total gastrectomy. From reference 1, with permission

\section{Indications}

\section{Early gastric cancer (EGC)}

The indication for LADG is EGC with a risk of lymph node metastasis. The incidence of lymph node metastasis is about $2 \%-5 \%$ in EGC patients with mucosal cancer and $11 \%-20 \%$ in those with submucosal cancer, as mentioned above [11-13]. Although there have been many studies pertaining to lymph node metastasis in EGC patients, the clinicopathological features of EGC without lymph node metastasis remain debatable. Ono et al. [7] found no lymph node metastasis associated with EGC in patients with differentiated mucosal carcinoma less than $3 \mathrm{~cm}$ in diameter without ulceration. Omote et al. [14] reported that submucosal cancers without lymph node metastasis were carcinomas less than $3 \mathrm{~cm}$ in diameter with less than $300 \mu \mathrm{m}$ of submucosal invasion. Oizumi et al. [15] and Fujii et al. [16] found no lymph node metastasis in patients with submucosal cancer of less than $1 \mathrm{~cm}$ in diameter. In Japan, EMR is a popular treatment for EGC without lymph node metastasis. This procedure is selected on the basis not only of clinicopathological findings but also based on the location of the tumor and the feasibility of the EMR technique. The Japanese Gastric Cancer Association guidelines for the treatment of gastric cancer [17] give the indication for EMR as differentiated mucosal carcinoma less than $2 \mathrm{~cm}$ in diameter without ulceration. ESD is a new technique by which a mucosal cancer less than $3 \mathrm{~cm}$ in diameter can be removed in one piece [7]. As the use of ESD has spread in Japan, the use of LWR and IGMR has decreased (Fig. 1). LWR or IGMR is now selected for the treatment of gastric cancer only if the tumor is located in the upper region or near the pyloric ring of the stomach. Therefore, LADG is used to treat EGC not indicated for ESD, LWR, or IGMR.

With LADG, three types of laparoscopic lymph node dissection are performed: perigastric lymph node dissection $(\mathrm{D} 1+\alpha)$, additional lymph node dissection along the common hepatic artery $(\mathrm{D} 1+\beta)$, and extended lymph node dissection (D2). In Japan, the type of lymph node dissection to be performed is always determined on the basis of preoperative clinical staging, according to the Japanese Gastric Cancer Association guidelines. However, the optimal lymph node dissection for EGC is disputed. Yasuda et al. [4] recommended D1 
$+\alpha$ lymph node dissection for submucosal cancer measuring $1-4 \mathrm{~cm}$ in diameter on the basis of their pathological investigations. Hyung et al. [18] proposed D2 lymph node dissection for differentiated submucosal cancer more than $2.5 \mathrm{~cm}$ in diameter and for undifferentiated submucosal cancer more $1.5 \mathrm{~cm}$. The Japanese Gastric Cancer Association guidelines have established the optimal lymph node dissection level for EGC as follows: $\mathrm{D} 1+\alpha$ for mucosal cancer not indicated for EMR and for differentiated submucosal cancer less than $1.5 \mathrm{~cm}$ in diameter; $\mathrm{D} 1+\beta$ for other submucosal cancers without preoperatively determined lymph node metastasis (N0) and for ECG less than $2.0 \mathrm{~cm}$ in diameter with preoperatively determined perigastric lymph node metastasis (N1); and D2 for EGC more than $2.0 \mathrm{~cm}$ in diameter with $\mathrm{N} 1$ metastasis.

As the number of patients with EGC who undergo EMR has increased, the number of patients with EGC requiring additional gastrectomy because of incomplete resection by EMR or recurrence after EMR has also increased. Korenaga et al. [19] reported that $55 \%$ of patients who underwent additional gastrectomy after EMR had submucosal cancer, and they emphasized the importance of diagnosis before EMR. Yano et al. [20] and our group [21] reported the usefulness of LADG for the treatment of remnant or recurrent cancer after EMR. A new treatment concept has been introduced involving the location and biopsy of sentinel lymph nodes in patients with EGC with possible metastasis [22]. Sentinel lymph node biopsy findings are used to guide laparoscopic lymph node dissection performed with ESD or LWR $[23,24]$.

\section{Advanced gastric cancer (AGC)}

The extent of lymph node dissection for AGC also remains controversial. In Asian countries, D2 lymph node dissection is routinely carried out for AGC. A laparoscopic D2 lymph node dissection technique was recently developed and is being performed in several Asian institutions. A national survey conducted by the Japan Society for Endoscopic Surgery (JSES) showed that D2 lymph node dissection was performed in $10 \%$ of patients treated by LADGs in Japan in 2003 [1].

AGC frequently recurs as peritoneal dissemination or hematogenous metastasis after curative surgery. However, the effects of laparoscopic surgery under $\mathrm{CO} 2$ pneumoperitoneum on the recurrence or progression of AGC are unknown. Park et al. [25] found, by clinicopathological examination, that gastric cancer without lymph node metastasis (N0) and confined to the muscularis propria had an excellent prognosis and could be treated with LADG. Several recent reports from Japan and Italy describe good long-term outcomes after LADG for AGC (T2N0) [26,27]. The Japanese Gastric
Cancer Association guidelines recognize LADG with D2 lymph node dissection for AGC (T2N0) as a new treatment option worthy of clinical research; a prospective randomized multicenter study is needed.

\section{$L A D G$ in obese patients and elderly patients}

LADG is usually performed by forceps through trocars under $\mathrm{CO} 2$ pneumoperitoneum at $10 \mathrm{mmHg}$. Mobilization of trocars in laparoscopic surgery is more restricted in obese patients than in normal-weight patients because of the thick abdominal wall with dense fat. Therefore, LADG in obese patients presents technical difficulties. There have been two studies of the feasibility of LADG in obese patients. Noshiro et al. [28] noted the following disadvantages of LADG in obese patients (body mass index $[\mathrm{BMI}] \geqq 24.2 \mathrm{~kg} / \mathrm{m}^{2}$ ) in comparison to normal-weight patients $\left(\mathrm{BMI}<24.2 \mathrm{~kg} / \mathrm{m}^{2}\right)$ : longer operation time, delayed recovery of bowel activity, higher rate of transition to open surgery, and higher frequency of Roux-en-Y used as a reconstruction method. However, they also showed advantages of LADG in obese patients, including a decreased incidence of serious wound and hernia complications after surgery. Yasuda et al. [29] showed the same rates of morbidity and mortality after LADG in obese $\left(B M I \geqq 25.0 \mathrm{~kg} / \mathrm{m}^{2}\right.$ ) and normal-weight patients $\left(\mathrm{BMI}<25.0 \mathrm{~kg} / \mathrm{m}^{2}\right)$. Thus, LADG for obese patients with EGC seems to be technically difficult, but feasible and minimally invasive.

Comorbidity is more common in elderly patients than in younger patients. Yasuda et al. [30] found that LADG offerred particular advantages to elderly patients (aged 70 years or more), including rapid return of gastrointestinal function, fewer complications, and a shorter hospital stay, in comparison to open surgery.

\section{Techniques}

\section{$L A D G$}

LADG with D1 $+\alpha$ lymph node dissection for EGC was developed and first reported by Kitano et al. [3] in 1994. Because a small laparotomy is required for laparoscopic gastrectomy, to remove the resected specimen from the abdominal cavity, gastrectomy and reconstruction by the Billroth-I method were performed through the small laparotomy with the original LADG method. This original procedure is performed as follows: (1) laparoscopic ligation and division of the major vessels and laparoscopic D1 $+\alpha$ lymph node dissection is carried out, and the stomach is fully mobilized; (2) resection of the distal two-thirds of the stomach is followed by the creation of a gastroduodenal anastomosis through a 5-cm-long minilaparotomy. As the minimal 
invasiveness and clinical usefulness of LADG became known, other types of laparoscopic surgery for gastric cancer were developed. Laparoscopic proximal gastrectomy (LAPG) [31,32] and total gastrectomy (LATG) [33], which are selected according to the EGC site, were developed in Japan. Also, laparoscopic pyloruspreserving gastrectomy [34,35] and laparoscopic gastrectomy with vagus nerve preservation [36] are performed as types of function-preserving gastrectomy. Furthermore, LATG with D2 lymph node dissection for AGC has been reported [37,38]. Anastomosis is now performed laparoscopically, and totally laparoscopic gastrectomy is gradually becoming popular $[39,40]$.

\section{Hand-assisted laparoscopic gastrectomy}

The technical disadvantages of laparoscopic surgery include the absence of touch sensation and limited movement of forceps. Therefore, hand-assisted techniques have been developed and adopted for the following surgeries requiring complex procedures: LADG with D2 lymph node dissection for AGC [41], LAPG [42], and LATG [43]. Ichihara et al. [44] reported fingerassisted and modified hand-assisted procedures. There are few studies evaluating the outcome of hand-assisted gastrectomy for gastric cancer. Kim et al. [45] compared hand-assisted gastrectomy with LADG and open distal gastrectomy (ODG), and concluded that hand-assisted gastrectomy may be an excellent learning technique as a surgeon gains experience in laparoscopic gastrectomy.

\section{Other techniques}

To perform LADG safely, Hyung et al. [46] reported the usefulness of endoscopic clips and laparoscopic ultrasonography to locate the tumor during LADG. Usui et al. [47] showed the importance in LADG of preoperative identification of vascular trees by threedimensional (3-D) computed tomographic angiography. Also, Takiguchi et al. [48] emphasized the usefulness of intraoperative navigation by means of 3-D angiocomputed tomography during extended lymph node dissection performed with LADG.

\section{Evaluation}

\section{Short-term outcome of $L A D G$}

Operative findings (Tables 1,2)

Laparoscopic surgery is performed with long forceps and coagulation shears under $\mathrm{CO}_{2}$ pneumoperitoneum and is accepted worldwide as a minimally invasive procedure. Although laparoscopic surgery is carried out with a clear amplified view of the operative field on the laparoscopy monitor, there is neither touch sensation nor an actual 3-D view of the internal structures. Therefore, the learning curve in the performance of LADG [49] and other laparoscopic surgeries should be considered to ensure that these procedures are performed safely.

Technical feasibility and surgical stress are evaluated in terms of operative findings, including operation time and blood loss. There have been seven retrospective case-controlled studies and two randomized controlled studies comparing the operative findings of LADG with those of open distal gastrectomy (ODG; Table 1). Six of these nine studies were of LADG with laparoscopic D1 $+\alpha$ or $\beta$ lymph node dissection, and the other three studies were of LADG with laparoscopic D2 lymph node dissection. The mean operation time for LADG ranged from $130 \mathrm{~min}$ to $320 \mathrm{~min}$, and the operation time was about $50 \mathrm{~min}$ longer for LADG than for ODG in four of the nine studies. The mean blood loss with LADG ranged from $60 \mathrm{~g}$ to $237 \mathrm{~g}$, and the blood loss with LADG was less than that with ODG in seven of the nine studies. In six reports pertaining to the outcome of LADG, the mean operation time and mean blood loss were from 150 to $330 \mathrm{~min}$ and from less than $200 \mathrm{~g}$ to $345 \mathrm{~g}$, respectively (Table 2). These results indicate that LADG is associated with longer operation time and less blood loss in comparison to ODG.

\section{Operative complications}

The technical difficulty of LADG affects the rate of conversion to open surgery and the incidence of operative complications. Most articles on operative complications during LADG describe case-control studies or case-series studies (Tables 1,2). Conversion to open surgery was reported in 5 of 15 studies; there was no conversion to open surgery in 10 . The rate of conversion ranged from $2.3 \%$ to $25 \%$, and the main reason for conversion to open surgery was extensive progression of the cancer, not intraoperative complications.

According to the JSES survey, the incidences of intraoperative and postoperative complications associated with LADG were $2.0 \%$ and $12 \%$, respectively. The most common intraoperative and postoperative complications were bleeding and anastomotic troubles, respectively. Interestingly, there was no significant difference in the incidence of intraoperative complications between LADG with D1 $+\alpha$ and LADG with D2 lymph node dissection. Usually, LADG with $\mathrm{D} 1+\alpha$ is performed as a procedure in the initial learning phase and D2 lymph node dissection is considered as an advanced procedure after certain experience with $\mathrm{D} 1+\alpha, \beta$ lymph node dissection. When performed by a surgeon with more advanced experience, the incidence of intraoperative complications during LADG with D2 lymph node dissection probably decreases. The morbidity rate 


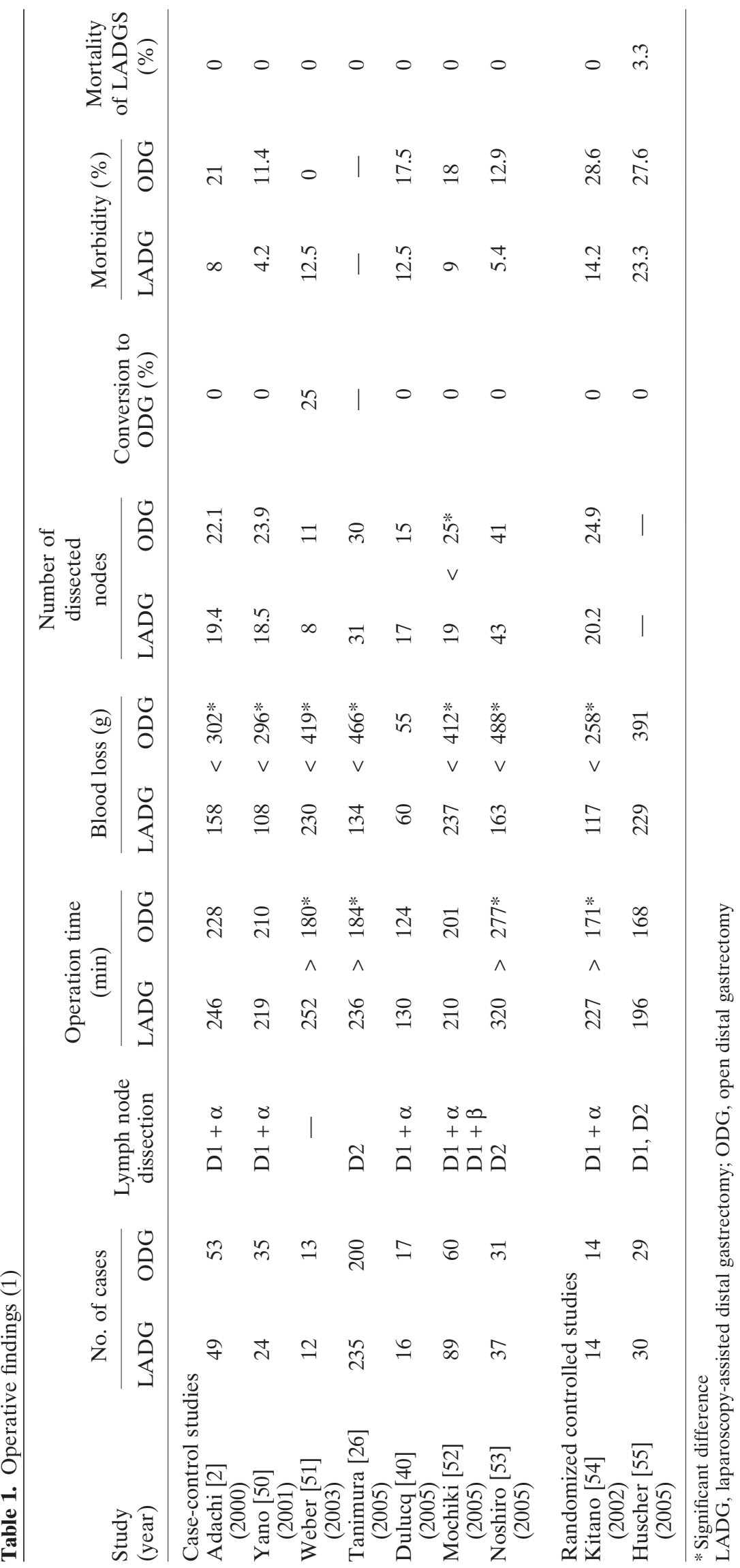


Table 2. Operative findings (2)

\begin{tabular}{|c|c|c|c|c|c|c|c|}
\hline $\begin{array}{l}\text { Study } \\
\text { (year) }\end{array}$ & $\begin{array}{l}\text { No. of } \\
\text { cases }\end{array}$ & $\begin{array}{l}\text { Lymph node } \\
\text { dissection }\end{array}$ & $\begin{array}{l}\text { Operation } \\
\text { time (min) }\end{array}$ & $\begin{array}{l}\text { Blood loss } \\
\text { (g) }\end{array}$ & $\begin{array}{c}\text { Conversion } \\
(\%)\end{array}$ & $\begin{array}{l}\text { Morbidity } \\
(\%)\end{array}$ & $\begin{array}{c}\text { Mortality } \\
(\%)\end{array}$ \\
\hline \multicolumn{8}{|c|}{ Case-series studies } \\
\hline $\begin{array}{l}\text { Asao } \\
\quad(2001,[56])\end{array}$ & 49 & $\mathrm{D} 1+\alpha$ & 280 & 297 & 0 & 6.1 & 0 \\
\hline $\begin{array}{l}\text { Mochiki } \\
\text { (2002, [57]) }\end{array}$ & 60 & $\mathrm{D} 1+\alpha, \beta$ & 238 & 252 & 0 & 9 & 0 \\
\hline $\begin{array}{l}\text { Fujiwara } \\
(2003,[58])\end{array}$ & 43 & $\mathrm{D} 1, \mathrm{D} 1+\alpha$ & 225 & 239 & 2.3 & 14 & 0 \\
\hline $\begin{array}{l}\text { Shimizu } \\
\quad(2003,[59])\end{array}$ & 76 & $\mathrm{D} 1+\alpha$ & 330 & 354 & 8 & 16 & 0 \\
\hline $\begin{array}{l}\text { Huscher } \\
\quad(2004,[27])\end{array}$ & 44 & D1, D2 & 224 & - & 7 & 12 & 7 \\
\hline $\begin{array}{l}\text { Carboni } \\
\quad(2005,[60])\end{array}$ & 20 & D2 & $150-300$ & $<200$ & 0 & 10 & 0 \\
\hline
\end{tabular}

reported for LADG seemed to be lower than that reported for ODG in all but one of six retrospective studies. In these retrospective studies, the mean morbidity rates for LADG and ODG were $10.1 \%$ and $16.1 \%$, respectively. In contrast, the mortality rate for LADG was $0 \%$ in all but 1 of 14 studies (Tables 1,2 ). In only 1 institution, a patient died of adult respiratory distress syndrome after LADG [27].

There have been only two randomized controlled trials (RCTs) comparing operative complications during LADG versus ODG (Table 1). Kitano et al. [54,61] reported no difference in the morbidity and mortality rates between LADG and ODG for EGC. An RCT by Huscher et al. [55], comparing the clinical outcomes of LADG with those of ODG for EGC and AGC showed that the morbidity and mortality rates were almost the same for the two operative procedures. These results suggest that LADG is technically feasible in patients with gastric cancer.

\section{Postoperative course}

Laparoscopic colectomy is known to have several advantages over open surgery, including less invasiveness, earlier return to normal life, and less pain [62]. Surgical stress during LADG has been investigated since the procedure came into use. To our knowledge, there have been seven case-control studies and only one RCT examining the postoperative course after LADG (Table 3). Five of these studies focused on patients with EGC alone, and three of the studies focused on patients with gastric cancer including AGC. The reported time to first flatus, normal diet, and walking, and the length of the hospital stays after LADG and ODG are summarized in Table 3. The data indicate that LADG results in a shorter time to first flatus, normal diet, and walking, and to earlier discharge. These results suggest that LADG is less invasive than ODG. Clinical pathway programs, which outline a patient's progress through specified stages of care, are now commonly used to improve patient quality of life (QOL) during hospitalization and to shorten hospital stay. These programs may affect the postoperative course after LADG and ODG.

\section{Biological response after surgery}

To clarify the surgical stress associated with LADG in comparison to that associated with ODG, postsurgical blood tests were performed in three retrospective studies. The subjects of these studies were patients with EGC. Adachi et al. [2] found that both the peak number of leukocytes and granulocytes and the peak concentration of C-reactive protein (CRP) after LADG were less than those after ODG and that the serum concentration of albumin was higher after LADG than after ODG. Migoh et al. [63] also reported a lower concentration of CRP after LADG than after ODG. Furthermore, Fujii et al. [64] found that the Th1/Th2 balance was less altered after LADG than after ODG. These results suggest that there is less surgical trauma associated with LADG than with ODG.

\section{Other studies}

Adachi et al. [65] examined patients' QOL after LADG in comparison to that after ODG and found that QOL in patients with EGC was better after LADG than after ODG. Goh et al. [66] performed an international questionnaire-based study and reported that 10 of 16 surgeons surveyed considered LADG to be superior to ODG because of faster recovery, less pain, and better cosmesis. Adachi et al. [67] compared the cost of LADG with that of ODG, and reported that LADG was less expensive than ODG because of the shorter hospital stay. 
Table 3. Postoperative course

\begin{tabular}{|c|c|c|c|c|c|c|c|c|c|c|c|c|c|c|c|}
\hline \multirow{2}{*}{$\begin{array}{l}\text { Study } \\
\text { (year) }\end{array}$} & \multicolumn{2}{|c|}{ No. of cases } & \multicolumn{3}{|c|}{$\begin{array}{l}\text { Time to first } \\
\text { flatus (POD) }\end{array}$} & \multicolumn{3}{|c|}{$\begin{array}{l}\text { Time to normal } \\
\text { diet (POD) }\end{array}$} & \multicolumn{3}{|c|}{$\begin{array}{c}\text { Time to first } \\
\text { walking (POD) }\end{array}$} & \multicolumn{3}{|c|}{$\begin{array}{l}\text { Length of stay } \\
\text { (days) }\end{array}$} & \multirow{2}{*}{$\begin{array}{c}\text { Other } \\
\text { advantages }\end{array}$} \\
\hline & LADG & ODG & LADG & & ODG & LADG & & ODG & LADG & & ODG & LADG & & ODG & \\
\hline \multicolumn{16}{|c|}{ Case-control studies } \\
\hline $\begin{array}{l}\text { Adachi } \\
\qquad(2000,[2])\end{array}$ & 49 & 53 & 3.9 & $<$ & $4.5^{*}$ & 5.0 & $<$ & $5.7 *$ & - & & - & 17.6 & $<$ & $22.5^{*}$ & $\begin{array}{l}\text { Less pain } \\
\text { and less } \\
\text { weight } \\
\text { loss }\end{array}$ \\
\hline $\begin{array}{l}\text { Yano } \\
\quad(2001,[50])\end{array}$ & 24 & 35 & 2.7 & $<$ & $3.5^{*}$ & 4.5 & $<$ & $5.5^{*}$ & 1.2 & $<$ & $2.3^{*}$ & 20.9 & $<$ & $29.4^{*}$ & Less pain \\
\hline $\begin{array}{l}\text { Weber } \\
\quad(2003,[51])\end{array}$ & 12 & 13 & - & & - & 3.3 & $<$ & $4.6^{*}$ & - & & - & 6.3 & $<$ & $10.4^{*}$ & - \\
\hline $\begin{array}{l}\text { Tanimura } \\
(2005,[26])\end{array}$ & 235 & 200 & 2.6 & $<$ & $3.6^{*}$ & 3.3 & $<$ & $6.0^{*}$ & - & & - & - & & - & - \\
\hline $\begin{array}{l}\text { Dulucq } \\
\quad(2005,[40])\end{array}$ & 16 & 17 & 2.9 & $<$ & $5.8^{*}$ & - & & - & - & & - & 16 & $<$ & $25 *$ & - \\
\hline $\begin{array}{l}\text { Mochiki } \\
\quad(2005,[52])\end{array}$ & 89 & 60 & - & & - & - & & - & - & & - & 17 & $<$ & $25 *$ & Less pain \\
\hline $\begin{array}{l}\text { Noshiro } \\
\qquad(2005,[53])\end{array}$ & 37 & 31 & 2.8 & $<$ & $3.4^{*}$ & 3.2 & $<$ & $4.2 *$ & 1.1 & & 1.2 & - & & - & - \\
\hline \multicolumn{16}{|c|}{ Randomized controlled study } \\
\hline $\begin{array}{l}\text { Kitano } \\
\qquad(2002,[54])\end{array}$ & 14 & 14 & 2.9 & $<$ & $3.9 *$ & 5.3 & & 4.5 & 1.8 & $<$ & $2.6^{*}$ & 17.6 & & 16.0 & Less pain \\
\hline
\end{tabular}

* Significant difference

LADG, laparoscopy-assisted distal gastrectomy; ODG, open distal gastrectomy; POD, postoperative days

\section{Oncological aspects}

Quality of lymph node dissection

The application of LADG for gastric cancer remains controversial because of the lack of clinical evidence relating to oncological issues. Several surgeons who regularly perform ODG suspect that lymph node dissection in LADG may be inadequate because of the technical difficulty of the procedure [57]. Therefore, the quality of lymph node dissection performed with LADG has been examined. The number of lymph nodes dissected with LADG versus ODG is shown in Table 1. The mean number of lymph node dissected by LADG with $\mathrm{D} 1+\alpha$ lymph node dissection was 19 nodes and was almost equivalent to that by ODG (21.7 nodes). These numbers suggest that the quality of lymph node dissection in LADG is equal to that in ODG.

\section{Survival and recurrence}

The 5-year disease-free survival and recurrence rates after LADG are summarized in Table 4. There have been only five studies pertaining to long-term outcome after LADG for EGC and three studies pertaining to long-term outcome after LADG for gastric cancer including AGC. The 5-year disease-free survival rate of patients with EGC who underwent LADG was almost $100 \%$. In a retrospective study, Huscher et al. [27] showed that the 3-year survival rate of patients with gastric cancer, including AGC, who underwent LADG was $69 \%$ during follow-up periods averaging 46 months (median, 25 months). In 2005, Huscher et al. [55] first reported the results of an RCT conducted to clarify the long-term outcome of LADG in comparison to that of ODG. The 5-year disease-free survival rate of patients with gastric cancer, including AGC, who underwent LADG did not differ significantly from that of patients who underwent ODG (57.3\% versus 58.9\%) [55]. The results of these studies suggest that LADG is an acceptable treatment for gastric cancer, from the oncological prospective. However, there has been no large-series multicenter RCT of the long-term outcome of LADG.

\section{Current status}

Since LADG for cancer was first reported by Kitano et al. [3] in 1994, use of the procedure has increased remarkably in Japan. A national JSES survey showed that about 7800 patients with gastric cancer underwent laparoscopic gastrectomy during the period 1991 through 2003 (Fig. 1) [1]. As EMR and ESD have developed and gained acceptance, the use of laparoscopic local resections such as LWR or IGMR has decreased slightly. In contrast, the use of LADG with lymph node dissection has become widespread; more than 1700 patients with gastric cancer underwent this procedure in 
Table 4. Survival and recurrence

\begin{tabular}{|c|c|c|c|c|c|c|c|}
\hline \multirow[b]{2}{*}{ Study (year) } & \multirow[b]{2}{*}{ Indication } & \multirow{2}{*}{$\begin{array}{l}\text { No. of } \\
\text { cases }\end{array}$} & \multicolumn{3}{|c|}{$\begin{array}{l}\text { 5-year disease-free } \\
\text { survival }(\%)\end{array}$} & \multirow{2}{*}{$\begin{array}{l}\text { No. of } \\
\text { patients with } \\
\text { recurrence }\end{array}$} & \multirow{2}{*}{$\begin{array}{l}\text { Average } \\
\text { follow-up period, } \\
\text { in months (median) }\end{array}$} \\
\hline & & & ECG & AGC & Total & & \\
\hline \multicolumn{8}{|l|}{ Case-series studies } \\
\hline Yano $(2001,[50])$ & EGC & 24 & - & - & - & 0 & 36 \\
\hline Kitano $(2002,[61])$ & EGC & 116 & $100 \%$ & - & - & 0 & $120(53)$ \\
\hline Fujiwara $(2003,[58])$ & EGC & 43 & - & - & - & 1 & 37 \\
\hline Huscher (2004, [27]) & All stages & 44 & - & - & $\begin{array}{c}69 \% \\
\text { (3-year survival) }\end{array}$ & 14 & $46(25)$ \\
\hline Tanimura $(2005,[26])$ & EGC, T2N0 & 235 & $100 \%$ & $\begin{array}{c}96 \% \\
\text { (3-year survival) }\end{array}$ & - & 2 & $120(44)$ \\
\hline Dulucq $(2005,[40])$ & All stages & 24 & - & - & - & 1 & 12 \\
\hline Mochiki (2002, [57]) & EGC & 60 & $100 \%$ & - & - & 0 & 60 \\
\hline \multicolumn{8}{|c|}{ Randomized controlled study } \\
\hline Huscher $(2005,[55])$ & All stages & 30 & - & - & $57.3 \%$ & 11 & $88(60)$ \\
\hline
\end{tabular}

Japan in 2003. This procedure still accounts for only $3 \%-4 \%$ of all surgeries for gastric cancer, but the spread of LADG has been surprisingly fast. LADG was first reported as a minimally invasive surgery for EGC. In recent years, LADG has developed in two directions: the application of LADG with D $1+\alpha$ or $\beta$ lymph node dissection to function-preserving gastrectomy for EGC and the establishment of techniques for LADG with extended (D2) lymph node dissection so that LADG can be used to treat AGC.

Several modified LADG techniques have been reported. Uyama et al. [35] and Taniguchi et al. [34] reported laparoscopic pylorus-preserving gastrectomy. Uyama et al. [36] developed laparoscopic gastrectomy with preservation of the vagal nerve for EGC. Tanaka et al. $[68,69]$ reported laparoscopic lymph node dissection with sentinel node biopsy after ESD, and Kitagawa et al. [24] proposed LWR with laparoscopic lymph node dissection after sentinel node biopsy. These modified LADGs are intended to provide a more minimally invasive surgery and to preserve function in patients with EGC.

The development of laparoscopic techniques and instruments, including laparoscopes with better visibility, and laparoscopic coagulation shears, has enabled us to perform laparoscopic extended (D2) lymph node dissection. In 1999, Azagra et al. [70] and Uyama et al. [37] reported LADG with D2 lymph node dissection for advanced cancer. The use of LADG has gradually increased in Japan, as shown in Fig.1 [1]. D2 lymph node dissection was performed with $11.2 \%$ of LADGs in 2003. The Japanese Gastric Cancer Association guidelines [17] state that LADG with D2 lymph node dissection is indicated for AGC without serosal invasion, and without preoperatively diagnosed lymph node metastasis, as a new treatment option worthy of clinical research.

\section{Conclusion}

Laparoscopic gastrectomy with lymph node dissection has developed as a minimally invasive surgery for gastric cancer over the past 15 years. This surgery has been used mainly for early-stage gastric cancer. The incidence of operative complications is the same as that with conventional open surgery. Laparoscopic gastrectomy has advantages over open surgery, including earlier recovery, shorter hospital stay, less pain, and better cosmesis. However, laparoscopic surgery for gastric cancer, especially advanced cancer, remains controversial, because there are few reliable studies of the long-term outcome. To establish laparoscopic surgery as a standard treatment for gastric cancer, multicenter RCTs comparing the short- and long-term outcomes of laparoscopic surgery versus open surgery are needed.

Acknowledgments This work was supported in part by a Grant-in-Aid for Cancer Research from the Japanese Ministry of Health, Labour, and Welfare (no. 13-17).

\section{References}

1. Japan Society for Endoscopic Surgery. Nationwide survey on endoscopic surgery in Japan (in Japanese) J Jpn Soc Endosc Surg 2004;9:475-563.

2. Adachi Y, Shiraishi N, Shiromizu A, Bandoh T, Aramaki M, Kitano S. Laparoscopy-assisted Billroth I gastrectomy compared with conventional open gastrectomy. Arch Surg 2000;135:806-10. 
3. Kitano S, Iso Y, Moriyama M, Sugimachi K. Laparoscopyassisted Billroth I gastrectomy. Surg Laparosc Endosc 1994;4: 146-8.

4. Yasuda K, Shiraishi N, Suematsu T, Yamaguchi K, Adachi Y, Kitano S. Rate of detection of lymph node metastasis is correlated with the depth of submucosal invasion in early stage gastric carcinoma. Cancer 1999;85:2119-23.

5. Ohgami M, Otani Y, Furukawa T, Kubota T, Kumai K, Kitajima M. Curative laparoscopic surgery for early gastric cancer: 8 years experience (in Japanese). Nippon Geka Gakkai Zasshi 2000;101: 539-45.

6. Ohashi S. Laparoscopic intraluminal (intragastric) surgery for early gastric cancer. Surg Endosc 1995;9:169-71.

7. Ono H, Kondo H, Gotoda T, Shirao K, Yamaguchi H, Saito D, et al. Endoscopic mucosal resection for treatment of early gastric cancer. Gut 2001:48:225-9.

8. Swanstrom LL, Pennings JL. Laparoscopic control of short gastric vessels. J Am Coll Surg 1995;181:347-51.

9. Uyama I, Sugioka A, Fujita J, Komori Y, Matsui H, Soga R, et al. Complete laparoscopic extraperigastric lymph node dissection for gastric malignancies located in the middle or lower third of the stomach. Gastric Cancer 1999;2:186-90.

10. Goh PM, Khan AZ, So JB, Lomanto D, Cheah WK, Muthiah R, et al. Early experience with laparoscopic radical gastrectomy for advanced gastric cancer. Surg Laparosc Endosc Percutan Tech 2001;11:83-7.

11. Namieno T, Koito K, Higashi T, Takahashi M, Yamashita K, Kondo Y, et al. Assessing the suitability of gastric carcinoma for limited resection: endoscopic prediction of lymph node metastasis. World J Surg 1998;22:859-64.

12. Nakamura K, Morisaki T, Sugitani A, Ogawa T, Uchiyama A, Kinukawa N, et al. An early gastric carcinoma treatment strategy based on analysis of lymph node metastasis. Cancer 1999;85:15005.

13. Kurihara N, Kubota T, Otani Y, Ohgami M, Kumai K, Sugiura H, et al. Lymph node metastasis of early gastric cancer with submucosal invasion. Br J Surg 1998;85:835-9.

14. Omote K, Mai M, Mizoguchi M, Takahashi Y, Kawashima A. Degree of submucosal invasion of early carcinoma and risk for lymph node metastasis: consideration limiting of applicability for endoscopic resection (in Japanese, with abstract in English). Stomach Intest 1997;32:49-55.

15. Oizumi H, Matsuda T, Fukase K, Monma T, Furusawa A, Mito S, et al. Endoscopic resection for early gastric cancer: the actual procedure and clinical evaluation (in Japanese, with abstract in English). Stomach Intest 1991;26:289-300.

16. Fujii K, Okajima K, Isozaki H, Hara H, Nomura E, Sako S, et al. A clinicopathological study on the indications of limited surgery for submucosal gastric cancer (in Japanese, with abstract in English). Jpn J Gastroenterol Surg 1998;31:2055-62.

17. Japanese Gastric Cancer Association. The guidelines for the treatment of gastric cancer. Tokyo: Kanehara; 2001.

18. Hyung WJ, Cheong JH, Kim J, Chen J, Choi SH, Noh SH, et al. Application of minimally invasive treatment for early gastric cancer. J Surg Oncol 2004;85:181-5.

19. Korenaga D, Orita H, Maekawa S, Maruoka A, Sakai K, Ikeda T, et al. Pathological appearance of the stomach after endoscopic mucosal resection for early gastric cancer. Br J Surg 1997;84:15636.

20. Yano H, Kimura Y, Iwazawa T, Monden T. Laparoscopic management for local recurrence of early gastric cancer after endoscopic mucosal resection. Surg Endosc 2005;19:981-5.

21. Shiraishi N, Hagino Y, Yasuda K, Bandoh T, Adachi Y, Kitano S, et al. Laparoscopic gastrectomy for early gastric cancer after endoscopic mucosal resection. Dig Endosc 1999;11:132-6.

22. Kitagawa Y, Ohgami M, Fujii H, Mukai M, Kubota T, Ando N, et al. Laparoscopic detection of sentinel lymph nodes in gastrointestinal cancer: a novel and minimally invasive approach. Ann Surg Oncol 2001;8:86-9.
23. Abe N, Mori T, Takeuchi H, Yoshida T, Ohki A, Ueki H, et al. Laparoscopic lymph node dissection after endoscopic submucosal dissection: a novel and minimally invasive approach to treating early-stage gastric cancer. Am J Surg 2005;190:496-503.

24. Kitagawa Y, Kitano S, Kubota T, Kumai K, Otani Y, Saikawa Y, et al. Minimally invasive surgery for gastric cancer — toward a confluence of two major streams: a review. Gastric Cancer 2005; 8:103-10.

25. Park SS, Kim CS, Mok YJ, Kim SJ, Kim HI. Gastric cancer confined to the muscularis propria: a possible candidate for laparoscopic surgery or adjuvant therapy. Scand J Gastroenterol 2005;40:450-4.

26. Tanimura S, Higashino M, Fukunaga Y, Kishida S, Nishikawa M, Ogata A, et al. Laparoscopic distal gastrectomy with regional lymph node dissection for gastric cancer. Surg Endosc 2005;19: $1177-81$.

27. Huscher CG, Mingoli A, Sgarzini G, Sansonetti A, Lirici MM, Napolitano C, et al. Videolaparoscopic total and subtotal gastrectomy with extended lymph node dissection for gastric cancer. Am J Surg 2004;188:728-35.

28. Noshiro H, Shimizu S, Nagai E, Ohuchida K, Tanaka M. Laparoscopy-assisted distal gastrectomy for early gastric cancer. Is it beneficial for patients of heavier weight? Ann Surg 2003; 238:680-5.

29. Yasuda K, Inomata M, Shiraishi N, Izumi K, Ishikawa K, Kitano S. Laparoscopy-assisted distal gastrectomy for early gastric cancer in obese and nonobese patients. Surg Endosc 2004;18:1253-6.

30. Yasuda K, Sonoda H, Shiroshita H, Inomata M, Shiraishi N, Kitano S. Laparoscopically assisted distal gastrectomy for early gastric cancer in the elderly. Br J Surg 2004;91:1061-5.

31. Kitano S, Adachi Y, Shiraishi N, Suematsu T, Bando T. Laparoscopic-assisted proximal gastrectomy for early gastric carcinomas. Surg Today 1999;29:389-91.

32. Uyama I, Sugioka A, Matsui H, Fujita J, Komori Y, Hatakawa Y, et al. Laparoscopic side-to-side esophagogastrostomy using a linear stapler after proximal gastrectomy. Gastric Cancer 2001;4:98102.

33. Mochiki E, Kamimura H, Haga N, Asao T, Kuwano H. The technique of laparoscopically assisted total gastrectomy with jejunal interposition for early gastric cancer. Surg Endosc 2002; 16:540-4.

34. Taniguchi S, Koga K, Ibusuki K, Sugio K, Uchimura Y. Laparoscopic pylorus-preserving gastrectomy with intracorporeal hand-sewn anastomosis. Surg Laparosc Endosc 1997;7:354-6.

35. Uyama I, Sugioka A, Fujita J, Komori Y, Matsui H, Soga R, et al. Purely laparoscopic pylorus-preserving gastrectomy with extraperigastric lymphadenectomy for early gastric cancer: a case and technical report. Surg Laparosc Endosc Percutan Tech 1999;9:418-22.

36. Uyama I, Sakurai Y, Komori Y, Nakamura Y, Syoji M, Tonomura $\mathrm{S}$, et al. Laparoscopic gastrectomy with preservation of the vagus nerve accompanied by lymph node dissection for early gastric carcinoma. J Am Coll Surg 2005;200:140-5.

37. Uyama I, Sugioka A, Fujita J, Komori Y, Matsui H, Hasumi A. Laparoscopic total gastrectomy with distal pancreatosplenectomy and D2 lymphadenectomy for advanced gastric cancer. Gastric Cancer 1999;2:230-4.

38. Goh PM, Khan AZ, So JB, Lomanto D, Cheah WK, Muthiah R, et al. Early experience with laparoscopic radical gastrectomy for advanced gastric cancer. Surg Laparosc Endosc Percutan Tech 2001;1:83-7.

39. Takaori K, Nonura E, Mabuchi H, Lee SW, Agui T, Miyamoto Y, et al. A secure technique of intracorporeal Roux-Y reconstruction after laparoscopic distal gastrectomy. Am J Surg 2005;189:17883.

40. Dulucq JL, Wintringer P, Perissat J, Mahajna A. Completely laparoscopic total and partial gastrectomy for benign and malignant disease: a single institute's prospective analysis. J Am Coll Surg 2005;200:191-7. 
41. Tanimura S, Higashino M, Fukunaga Y, Osugi H. Hand-assisted laparoscopic distal gastrectomy with regional lymph node dissection for gastric cancer. Surg Laparosc Endosc Percutan Tech 2001;11:155-60.

42. Tanimura S, Higashino M, Fukunaga Y, Osugi H. Laparoscopic gastrectomy with regional lymph node dissection for upper gastric cancer. Gastric Cancer 2003;6:64-8.

43. Kim YW, Han HS, Fleischer GD. Hand-assisted laparoscopic total gastrectomy. Surg Laparosc Endosc Percutan Tech 2003;13: 26-30.

44. Ichihara T, Takada M, Fukumoto S, Yasuda T, Kuroda Y. A novel technique of finger-assisted laparoscopic surgery. Am J Surg 2004;187:285-7.

45. Kim YW, Bae JM, Lee JH, Ryu KW, Choi IJ, Kim CG, et al. The role of hand-assisted laparoscopic distal gastrectomy for distal gastric cancer. Surg Endosc 2005;19:29-33.

46. Hyung WJ, Lim JS, Cheong JH, Kim J, Choi SH, Song SY, et al. Intraoperative tumor localization using laparoscopic ultrasonography in laparoscopic-assisted gastrectomy. Surg Endosc 2005; 19:1353-7.

47. Usui S, Hiranuma S, Ichikawa T, Maeda M, Kudo SE, Iwai T. Preoperative imaging of surrounding arteries by threedimensional CT. Surg Laparosc Endosc Percutan Tech 2005;15: $61-5$.

48. Takiguchi S, Sekimoto M, Fujiwara Y, Yasuda T, Yano M, Hori $\mathrm{M}$, et al. Laparoscopic lymph node dissection for gastric cancer with intraoperative navigation using three-dimensional angio computed tomography images reconstructed as laparoscopic view. Surg Endosc 2004;18:106-10.

49. Yasuda K, Shiraishi N, Inomata M, Fujii K, Sonoda K, Kitano S, et al. Learning curve for laparoscopy-assisted distal gastrectomy. Dig Endosc 2003;15:280-3.

50. Yano H, Monden T, Kinuta M, Nakano Y, Tono T, Matsui S, et al. The usefulness of laparoscopy-assisted distal gastrectomy in comparison with that of open distal gastrectomy for early gastric cancer. Gastric Cancer 2001:4:93-7.

51. Weber KJ, Reyes CD, Gagner M, Divino CM. Comparison of laparoscopic and open gastrectomy for malignant disease. Surg Endosc 2003;17:968-71.

52. Mochiki E, Kamiyama Y, Aihara R, Nakabayashi T, Asao T, Kuwano H. Laparoscopic assisted distal gastrectomy for early gastric cancer: 5 years' experience. Surgery 2005;137:317-22.

53. Noshiro H, Nagai E, Shimizu S, Uchiyama A, Tanaka M. Laparoscopically assisted distal gastrectomy with standard radical lymph node dissection for gastric cancer. Surg Endosc 2005;19: 1592-6.

54. Kitano S, Shiraishi N, Fujii K, Yasuda K, Inomata M, Adachi Y. A randomized controlled trial comparing open vs laparoscopyassisted distal gastrectomy for the treatment of early gastric cancer: an interim report. Surgery 2002;131:S306-11.

55. Huscher CGS, Mingoli A, Sgarzini G, Sansonetti A, Di Paola M, Recher A, et al. Laparoscopic versus open subtotal gastrectomy for distal gastric cancer. Five-year results of a randomized prospective trial. Ann Surg 2005;241:232-7.
56. Asao T, Hosouchi Y, Nakabayashi T, Haga N, Mochiki E, Kuwano H. Laparoscopically assisted or distal gastrectomy with lymph node dissection for early gastric cancer. Br J Surg 2001;88: 128-32.

57. Mochiki E, Nakabayashi T, Kamimura H, Haga N, Asao T, Kuwano H. Gastrointestinal recovery and outcome after laparoscopy-assisted versus conventional open distal gastrectomy for early gastric cancer. World J Surg 2002;26:1145-9.

58. Fujiwara M, Kodera Y, Kasai Y, Kanyama Y, Hibi K, Ito K, et al. Laparoscopy-assisted distal gastrectomy with systemic lymph node dissection for early gastric carcinoma: a review of 43 cases. J Am Coll Surg 2003;196:75-81.

59. Shimizu S, Noshiro H, Nagai E, Uchiyama A, Tanaka M. Laparoscopic gastric surgery in a Japanese institution: analysis of the initial 100 procedures. J Am Coll Surg 2003;197:372-8.

60. Carboni F, Lepiane P, Santoro R, Mancini P, Lorusso R, Santoro E. Laparoscopic surgery for gastric cancer: preliminary experience. Gastric Cancer 2005;8:75-7.

61. Kitano S, Shiraishi N, Kakisako K, Yasuda K, Inomata M, Adachi Y. Laparoscopy-assisted Billroth-I gastrectomy (LADG) for cancer: our 10 years' experience. Surg Laparosc Endosc Percutan Tech 2002;12:204-7.

62. Khalili TM, Fleshner PR, Hiatt JR, Sokol TP, Manookian C, Tsushima G, et al. Colorectal cancer: comparison of laparoscopic with open approaches. Dis Colon Rectum 1998;41:832-8.

63. Migoh S, Hasuda K, Nakashima K, Anai H. The benefit of laparoscopy-assisted distal gastrectomy compared with conventional open distal gastrectomy: a case-matched control study. Hepatogastroenterology 2003;50:2251-4.

64. Fujii K, Sonoda K, Izumi K, Shiraishi N, Adachi Y, Kitano S. T lymphocyte subsets and Th1/Th2 balance after laparoscopyassisted distal gastrectomy. Surg Endosc 2003;17:1440-4.

65. Adachi Y, Suematsu T, Shiraishi N, Katsuta T, Morimoto A, Kitano S, et al. Quality of life after laparoscopy-assisted Billroth I gastrectomy. Ann Surg 1999;229:49-54.

66. Goh PMY, Alponat A, Mak K, Kum CK. Early international results of laparoscopic gastrectomies. Surg Endosc 1997;11:650-2.

67. Adachi Y, Shiraishi N, Ikebe K, Aramaki M, Bandoh T, Kitano S. Evaluation of the cost for laparoscopic-assisted Billroth I gastrectomy. Surg Endosc 2001;15:932-6.

68. Tanaka K, Kobayashi M, Konishi N, Ohmori Y, Mohri Y, Tonouchi $\mathrm{H}$, et al. Laparoscopic intraoperative detection of micrometastatic sentinel nodes by immunohistochemical staining in patients with early gastric cancer. Surg Endosc 2003;17:988-9.

69. Tanaka K, Tonouchi H, Kobayashi M, Konishi N, Ohmori Y, Mohri Y, et al. Laparoscopically assisted total gastrectomy with sentinel node biopsy for early gastric cancer: preliminary results. Am Surg 2004;70:976-81.

70. Azagra JS, Goergen M, De Simone P, Ibanez-Aguirre J. Minimally invasive surgery for gastric cancer. Surg Endosc 1999;13: 351-7. 